\title{
Article \\ Correlation between Heavy Metal-Induced Histopathological Changes and Trophic Interactions between Different Fish Species
}

\author{
Bianca Onita (Mladin) ${ }^{1,+}$, Paul Albu ${ }^{2,+}{ }^{,}$Hildegard Herman ${ }^{1} @$, Cornel Balta ${ }^{1}$, Vasile Lazar ${ }^{3}$, Andras Fulop ${ }^{4}$, \\ Edina Baranyai ${ }^{5}$, Sándor Harangi ${ }^{5}$, Sandor Keki ${ }^{6}{ }^{1}$, Lajos Nagy ${ }^{6}$, Tibor Nagy ${ }^{6}{ }^{\infty}$, Vilmos Józsa ${ }^{7}$, Dénes Gál ${ }^{7}$, \\ Károly Györe ${ }^{7}$, Miruna Stan ${ }^{8} \mathbb{1}$, Anca Hermenean ${ }^{1, * \mathbb{C}}$ and Anca Dinischiotu ${ }^{8}$
}

Citation: Onita (Mladin), B.; Albu, P.; Herman, H.; Balta, C.; Lazar, V.; Fulop, A.; Baranyai, E.; Harangi, S.; Keki, S.; Nagy, L.; et al. Correlation between Heavy Metal-Induced Histopathological Changes and Trophic Interactions between Different Fish Species. Appl. Sci. 2021, 11,3760. https://doi.org/10.3390/ app11093760

Academic Editors: Hans-Uwe Dahms, Chi-Ying Hsieh and Jin-Hyoung Kim

Received: 11 March 2021

Accepted: 20 April 2021

Published: 21 April 2021

Publisher's Note: MDPI stays neutral with regard to jurisdictional claims in published maps and institutional affiliations.

Copyright: (c) 2021 by the authors. Licensee MDPI, Basel, Switzerland. This article is an open access article distributed under the terms and conditions of the Creative Commons Attribution (CC BY) license (https:// creativecommons.org/licenses/by/ $4.0 /)$.
1 "Aurel Ardelean" Institute of Life Sciences, "Vasile Goldiș" Western University of Arad, 86 Revolution Str., 3010414 Arad, Romania; biancaonitamaria@gmail.com (B.O.); hildegard.i.herman@gmail.com (H.H.); baltacornel@gmail.com (C.B.)

2 Department of Pharmaceutical Sciences, Faculty of Pharmacy, "Vasile Goldis" Western University of Arad, 3010414 Arad, Romania; albupaul@yahoo.com

3 Satu-Mare Branch, "Vasile Goldis" Western University of Arad, 440114 Satu-Mare, Romania; vasilazar@yahoo.com

4 TS Labor, 1047 Budapest, Hungary; andreey77@yahoo.com

5 Agilent Atomic Spectrometry Partner Laboratory, Department of Inorganic and Analytical Chemistry, University of Debrecen, 4032 Debrecen, Hungary; baranyai.edina@science.unideb.hu (E.B.); harangi.sandor@science.unideb.hu (S.H.)

6 Department of Applied Chemistry, University of Debrecen, 4032 Debrecen, Hungary; keki.sandor@science.unideb.hu (S.K.); nagy.lajos@science.unideb.hu (L.N.); nagy.tibor@science.unideb.hu (T.N.)

7 National Agriculture Research and Innovation Centre, Research Institute for Fisheries and Aquaculture (HAKI), 5540 Szarvas, Hungary; jozsa.vilmos@haki.naik.hu (V.J.); gal.denes@szarvasnet.hu (D.G.); gyorek123@szarvasnet.hu (K.G.)

8 Department of Biochemistry and Molecular Biology, University of Bucharest, 050095 Bucharest, Romania; miruna.stan@bio.unibuc.ro (M.S.); ancadinischiotu@yahoo.com (A.D.)

* Correspondence: anca.hermenean@gmail.com

+ These authors contributed equally to this work.

Abstract: This study assessed the distribution of heavy metals in the gills, kidney, and liver, correlated with the severity of histopathological changes, of three fish species with different feeding habitats (Barbus barbus, Squalius cephalus, and Chondrostoma nasus) from the Crisul Negru river, Romania. The levels of copper $(\mathrm{Cu})$, chromium $(\mathrm{Cr})$, cadmium $(\mathrm{Cd})$, lead $(\mathrm{Pb})$, and zinc $(\mathrm{Zn})$ in fish tissues were measured by atomic absorption spectrophotometry. Histopathology and the expressions of TNF- $\alpha$ and proliferation cell nuclear antigen (PCNA) were investigated by immunohistochemistry and Western blot. Our data suggest a significant correlation between the bioconcentration level of metals and structural changes. The carnivorous species was the most affected compared to the omnivorous and herbivorous ones, and the most affected organ was the kidney. Moreover, the correlation of tissue damage with the PCNA and TNF- $\alpha$ expression levels revealed that the herbivorous species presented less extended lesions, likely due to higher activated repair mechanisms and lower levels of inflammation. In conclusion, our data and the subsequent statistical analysis suggest that feeding behavior could be correlated with the histopathological alterations and might be used for a more profound evaluation of aquatic environment safety and analysis of aquatic ecosystems.

Keywords: fish; metals; bioaccumulation; gills; kidney; liver; histopathology; trophic interactions

\section{Introduction}

The evolution of human civilization has involved the development of new materials and technologies that have generated air, soil, and water pollution. Ecological toxic 
substances and natural or man-made chemicals as well as biological ones exert a deleterious effect on plants, animals, and humans at doses of milligrams or micrograms per $\mathrm{kg}$ [1]. Inorganic pollutants are spread in the environment due to different anthropogenic activities, such as mine drainage, smelting, metallurgical and other industrial processes, as well as natural ones, such as volcanic eruptions, sea-salt sprays, forest fires, rock erosion, and wind-borne soil particles [2]. Among the inorganic pollutants, heavy metals are very important due to their toxicity for terrestrial and aquatic life.

The metal pollution of surface waters is mainly due to water discharged from the extraction and processing of ores [3]. These effluents are mine or flotation waters and wastewater from metal processing units or chemical industry that were untreated or insufficiently treated and discharged into natural water bodies (e.g., rivers, lakes, canals). Heavy metals are deposited in large quantities in the sediment at the bottom of the river bed. Metals and organic chemicals are taken up from the aquatic environment by biota either via the water phase, food, or by direct contact with the sediment [4]. Bioaccumulation of heavy metals in fish occurs with different patterns depending on tissue type, deposition and excretion rates, as well as water acidification, hardness, salinity, and temperature. Various species of fish from the same water body can bioconcentrate different amounts of metals depending on their living and feeding habits [5]. The affinity of specific metals for fish organs can differ [5].

Essential and non-essential heavy metals are important in environmental toxicology due to their toxicity, long persistence, bioaccumulation, and biomagnification in the food chain [6]. They are taken up by the fish living in contaminated water bodies through their gills, gastrointestinal tract, and skin [7]. Once absorbed in the fish's body, the metal ions enter the blood and are carried to a storage point or to the liver (which is the main site of accumulation of these [8]), kidney, or digestive tract [5].

Metals, such as $\mathrm{Cu}, \mathrm{Co}, \mathrm{Mn}$, and $\mathrm{Zn}$, are essential for animals, being involved in cellular metabolism, antioxidant and anti-inflammatory defenses, gene expression, and protein synthesis [9]. Excessive environmental concentrations of these become toxic for animals and plants.

Other metals, such as $\mathrm{Cd}, \mathrm{Cr}$, and $\mathrm{Pb}$, are not involved in the metabolic pathways $[10,11]$. $\mathrm{Cd}$ and $\mathrm{Pb}$ are accumulated primarily in the kidney and liver, but they may reach high concentrations also in the gills, digestive tract, and spleen [5]. The kidney in particular, but also the liver and gills, can accumulate $\mathrm{Cr}$ [11].

Redox active metals $(\mathrm{Cu}, \mathrm{Cr}, \mathrm{Mn}$ ) generate reactive oxygen species (ROS) by Fenton and Haber-Weiss reactions [12]. Those without this property interact with thiol groups of reduced glutathione and enzymes, disrupting the antioxidant defense system [13] and generating oxidative stress. There is a direct correlation between oxidative stress and histological alterations of different tissues [14].

Exposure of fish to several heavy metals $(\mathrm{Cu}, \mathrm{Cr}, \mathrm{Pb}, \mathrm{Cd})$ can induce the upregulation of proinflammatory genes [15,16].

The Crișul Negru river is one of the three rivers of the Cris basin located in the NW region of Romania with a total surface of $25,537 \mathrm{~km}^{2}$, collecting tributaries from a heavily mined area of outcrop rocks with a high content of heavy metals [17]. The main rivers of this basin meet in pairs in Hungary, in a single course of the river Tisza. According to the data provided by Banarescu et al. [18], sixty years ago, the ichthyofauna of the Crișul Negru consisted of 33 species. Nowadays, their number has been reduced to 20 species [19]. The drastic reduction in number of species was due to anthropogenic pressure and pollution contaminants. For this study, we have chosen a collecting point known to have polluted water, where the ichthyofauna are characterized by the Barbus barbus, Chondrostoma nasus, and Squalius cephalus species according to Gergely et al. [19].

In this context, we studied the histopathological alterations and protein expression of TNF- $\alpha$ and proliferation cell nuclear antigen (PCNA) induced by heavy metal exposure on three species of cyprinides: Barbus barbus (BB), Squalius cephalus (SC), and Condostroma nasus $(\mathrm{CN})$, widely distributed throughout the selected sampling point of the Crișul Negru river, 
in correlation with their accumulation in water, sediment, and tissues (liver, kidney, and gill), in order to test the hypothesis that fish in the upper food chain position are prone to accumulate higher quantities of metals and develop more severe biological consequences.

\section{Materials and Methods}

\subsection{Sampling}

In this study, a representative polluted sampling site was chosen along the Crișul Negru river (Figure 1).

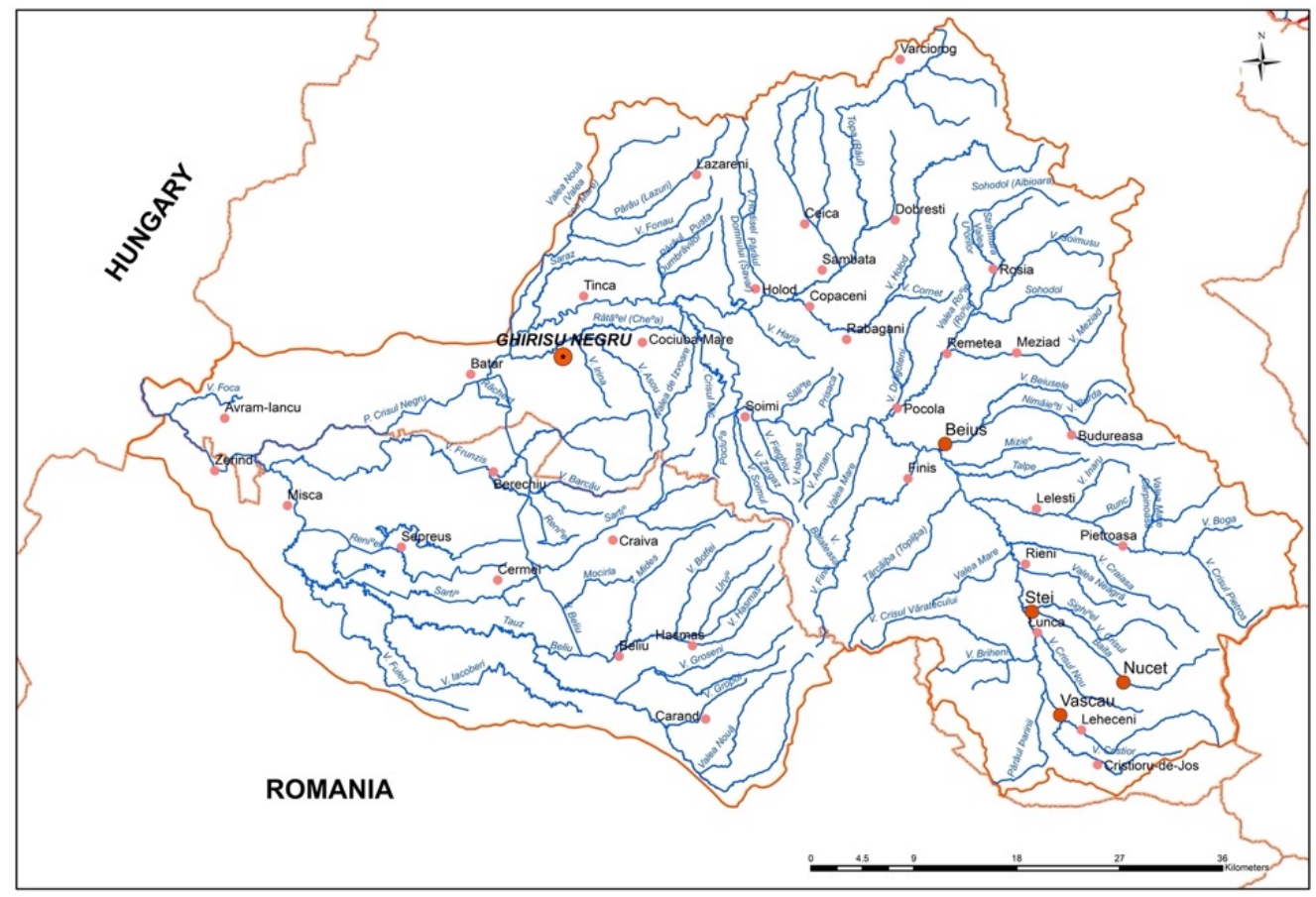

Figure 1. Schematic map of the Crișul Negru River showing sampling site (Ghirisu Negru).

These three analyzed species, dominant in the ichtyofauna site and belonging to different feeding habitats (Table 1), i.e., Barbus barbus (BB), Chondrostoma nasus (CN), and Squalius cephalus (SC), were captured alive by electrofishing for further analyses (15 individual, 5 fish/species).

Table 1. Classification and the main feeding habits of fish species sampled from the Crișul Negru river.

\begin{tabular}{|c|c|c|c|}
\hline Species & Family & Order & Main Feeding Habit \\
\hline Barbus barbus & Cyprinidae & Cypriniformes & $\begin{array}{l}\text { Mainly carnivorous (benthic organisms, including crustaceans, } \\
\text { insect larvae and mollusks) }\end{array}$ \\
\hline Chondrostoma nasus & Cyprinidae & Cypriniformes & Herbivorous (algae and other aquatic plants) \\
\hline Squalius cephalus & Cyprinidae & Cypriniformes & Omnivorous (aquatic and terrestrial animal and plant material) \\
\hline
\end{tabular}

Sampling took place during one day in summer (August 2015), in daylight, using a fishing device carried by one of the operators, while the other one was carrying the anode through the water. The identification of the species was carried out immediately after capture. Each individual was weighed and measured and observations were made regarding possible diseases and parasites. The healthy fish, with lengths between 20 and $25 \mathrm{~cm}$ and a wet weight ranging from 200 to $250 \mathrm{~g}$, were included in the study. The fish were washed using deionized water, anesthetized with benzocaine $\left(0.1 \mathrm{~g} \mathrm{~L}^{-1}\right)$, and killed by medullar sectioning; then, the gills, kidney, and liver tissues were placed in clean isolated polyethylene bags with ice and immediately taken to the laboratory in the Vasile Goldis 
Western University of Arad. The experimental procedures were approved by the Research Ethical Committee of the Vasile Goldis Western University of Arad.

Water and sediment sampling were carried out on the same day and location, and the samples were stored immediately at $4{ }^{\circ} \mathrm{C}$ until the laboratory analysis.

\subsection{Heavy Metals Concentration in Water and Sediments}

The water and sediment samples collected three times from the site were mineralized in a solution containing $65 \%$ nitric acid and $30 \%$ hydrogen peroxide. The metals were determined using flame Atomic Absorption Spectroscopy, and the concentrations were expressed in $\mathrm{mg} / \mathrm{dm}^{3}$ for the water samples and $\mathrm{mg} / \mathrm{kg}$ dry for the sediment samples.

\subsection{Bioaccumulation of Heavy Metal in the Gills, Liver, and Kidney}

The tissue samples were stored at $-80{ }^{\circ} \mathrm{C}$ until the analyses were performed. The samples were lyophilized with an Alpha 1-4 type instrument (Martin Christ Gefriertrocknungsanlagen, Osterode am Harz, Germany) and digested by a MLS 1200 mega (Milestone) microwave digestion system using a volume of $4 \mathrm{~mL} 69 \% \mathrm{HNO}_{3}$ and $0.25 \mathrm{~mL} \mathrm{30} \% \mathrm{H}_{2} \mathrm{O}_{2}$ per sample. The program of the microwave digestion system was set as follows: 5 min $25 \%$ $(300 \mathrm{~W}), 5 \mathrm{~min} 50 \%(600 \mathrm{~W})$, and $5 \mathrm{~min}$ ventilation $0 \%(0 \mathrm{~W})$.

The trace metal quantification $(\mathrm{Cd}, \mathrm{Cr}, \mathrm{Cu}, \mathrm{Zn}$, and $\mathrm{Pb}$, respectively) was performed by microwave plasma atomic emission spectroscopy using a 4100 MP-AES equipment (Agilent Technologies, Santa Clara, CA, USA) with an external gas control module. The sample introduction was performed with a concentric nebulizer. The required $\mathrm{N}_{2}$ was continuously generated by a $4107 \mathrm{~N}_{2}$ generator (Agilent Technologies, Santa Clara, CA, USA). The results were evaluated using MP Expert software.

\subsection{Histopathology}

Histological analysis was performed for each sample. The gills, liver, and kidney tissues were fixed in $4 \%$ paraformaldehyde phosphate buffered solution and embedded in paraffin using a standard protocol. Sections were cut into $5 \mu \mathrm{m}$ thick sections and stained with hematoxylin and eosin (H\&E) according to the methods provided by Bio-Optica staining kits.

Histopathological changes were analyzed and ranked for the severity of lesions as belonging to grades from 1 to 3 (Table 2), modified according to previous works [20-22]. For each organ, a "lesion grade" was calculated as mean \pm SEM.

Table 2. Histopathological changes ranked for the severity of lesions.

\begin{tabular}{|c|c|c|}
\hline Tissue & Grade & Histopathological Changes \\
\hline \multirow{3}{*}{ Gills } & 1 & $\begin{array}{c}\text { gill epithelium hyperplasia and hypertrophy, blood congestion, epithelial lifting of the lamellae, fusion or } \\
\text { lamellar disorganization }\end{array}$ \\
\hline & 2 & incomplete fusion of the secondary lamellae, incomplete epithelium break, epithelial cell desquamation \\
\hline & 3 & $\begin{array}{c}\text { lamellar aneurysm, epithelial cells break with hemorrhage, complete fusion of all the lamellae, lamellar } \\
\text { epithelium break }\end{array}$ \\
\hline \multirow{3}{*}{ Liver } & 1 & normal aspect of hepatocytes, sinusoids slightly dilated \\
\hline & 2 & sinusoids slightly dilated and connective tissue expansion \\
\hline & 3 & hypertrophic hepatocytes with vacuolated cytoplasm, dilated sinusoids \\
\hline \multirow{3}{*}{ Kidney } & 1 & normal aspect of hematopoietic tissue, slightly dilated renal tubuli \\
\hline & 2 & mild dilated tubular epithelial cells and glomeruli/contraction \\
\hline & 3 & $\begin{array}{c}\text { hypertrophy or tubular/damaged renal tubuli, glomerular contraction, connective tissue expansion, decrease } \\
\text { of the hematopoietic tissue }\end{array}$ \\
\hline
\end{tabular}




\subsection{Immunohistochemistry}

For immunolocalization of TNF- $\alpha$ and PCNA in the gills, liver, and kidney samples, a rabbit ABC Staining System, Santa-Cruz Biotechnology (San Diego, CA, USA) was used. The incubation with primary antibody (1:100 diluted) overnight at $4{ }^{\circ} \mathrm{C}$ was followed by the incubation with horseradish peroxidase (HRP)-conjugated secondary goat anti-rabbit IgG antibody (1:5000 dilution) and stained with the chromogenic substrate, 3,3'- diaminobenzidine chromogen (DAB). The nuclei were counterstained with Hematoxylin Gill 2 (Merck), and the samples were analyzed under a microscope (Olympus BX43 microscope).

\subsection{Protein Extraction and Western Blot Analysis}

The protein extraction was performed from $50 \mathrm{mg}$ samples with Tissue Protein Extraction Reagent (TPER) (ThermoFischer Scientific, Rockford, IL, USA). All samples were diluted to $50 \mu \mathrm{g}$ protein/well with TPER reagent. After denaturation with 1:1 Laemmli buffer (Bio-Rad Laboratories, Hercules, CA, USA), proteins were separated by SDS-PAGE electrophoresis on Mini-PROTEAN TGX Stain-free Precast Gels (Bio-Rad Laboratories, Hercules, CA, USA) with Tris/Glycine/SDS premixed electrophoresis buffer (Bio-Rad Laboratories, Hercules, CA, USA) at $90 \mathrm{~V}$ for $1.5 \mathrm{~h}$. After that, the proteins were transferred onto $0.20 \mu \mathrm{m}$ polyvinylidene difluoride (PVDF) membranes (Bio-Rad Laboratories, Hercules, CA, USA) at $25 \mathrm{~V}$ for $5 \mathrm{~min}$ with a Bio-Rad Trans-Blot Turbo Transfer System (Bio-Rad Laboratories, Hercules, CA, USA). The next steps (membrane blocking, incubation antibodies with chromogen solution) were performed using the WesternBreeze Chromogenic kit (Invitrogen, Carlsbad, CA, USA), and the membranes were processed according to the manufacturers' instructions. The primary antibodies, anti-TNF- $\alpha$ rabbit polyclonal antibody (Abcam, Cambridge, UK) and anti-PCNA rabbit polyclonal antibody (Santa Cruz Biotechnology, Santa Cruz, CA, USA), at a dilution of 1:150 were used overnight for membrane hybridization. The secondary antibodies used were those provided with the WesternBreeze kits. Blots were scanned using Bio-Rad ChemiDoc MP Imaging System (Bio-Rad Laboratories, Hercules, CA, USA). Densitometry of protein bands was carried out using the ImageJ 1.42 software (NIH Bethesda, MD, USA), and values were expressed as a percentage of the total size and density of all bands (intensities).

\subsection{Statistical Analysis}

A two-way analysis of variance ANOVA (GraphPad Prism, version 3.0) was applied to evaluate and compare the concentrations of metals and TNF- $\alpha$ and PCNA expression in different tissues from distinct species and to correlate the metal levels with histopathological lesion grade and inflammation (TNF- $\alpha$ level) or tissue recovery (PCNA level) with lesions grade. Data were presented as mean \pm SEM. Post hoc analyses of the significant means were performed using the Bonferroni test.

\section{Results and Discussion}

\subsection{Heavy Metal Concentrations in Water and Reservoir Sediments}

Metals concentrations in the Crișul Negru water and sediments are shown in the Table 3. Average levels of $\mathrm{Zn}, \mathrm{Cr}, \mathrm{Pb}, \mathrm{Cu}$, and $\mathrm{Cd}$ in the sediments were $66.46 \mathrm{mg} / \mathrm{kg}$, $35.95 \mathrm{mg} / \mathrm{kg}, 30.40 \mathrm{mg} / \mathrm{kg}, 19.51 \mathrm{mg} / \mathrm{kg}$, and $2.5 \mathrm{mg} / \mathrm{kg}$, respectively. The abundance of metals in the sediments varied in the following sequence: $\mathrm{Zn}>\mathrm{Cr}>\mathrm{Pb}>\mathrm{Cu}>\mathrm{Cd}$.

Table 3. Concentration of trace elements (mean; range) in sediments (mg/kg dry weight).

\begin{tabular}{ccc}
\hline Heavy Metal & Water $\left(\mathbf{m g} / \mathbf{d m}^{3}\right)$ & Sediment $\mathbf{( m g} / \mathbf{k g}$ Dry Weight $)$ \\
\hline $\mathrm{Cd}$ & $<0.001$ & $2.5 ; 2.5-2.5$ \\
$\mathrm{Cr}$ & $<0.01$ & $35.95 ; 27.75-42.37$ \\
$\mathrm{Cu}$ & $<0.05$ & $19.51 ; 17.91-21.53$ \\
$\mathrm{~Pb}$ & $<0.003$ & $30.40 ; 24.48-33.73$ \\
$\mathrm{Zn}$ & $<0.05$ & $66.46 ; 61.10-69.50$ \\
\hline
\end{tabular}




\subsection{Metal Bioaccumulation in the Gills, Liver, and Kidneys}

The analysis of the data is presented in Figure 2. A two-way analysis of variance was applied to evaluate and compare the concentrations of metals in different tissues from all three species analyzed with different feeding habits: carnivorous (BB), omnivorous (SC), and herbivorous $(\mathrm{CN})$.

A.

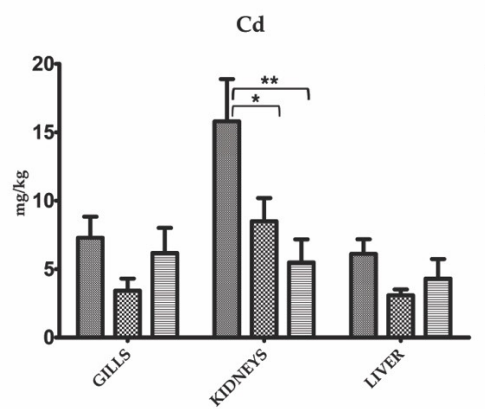

c.

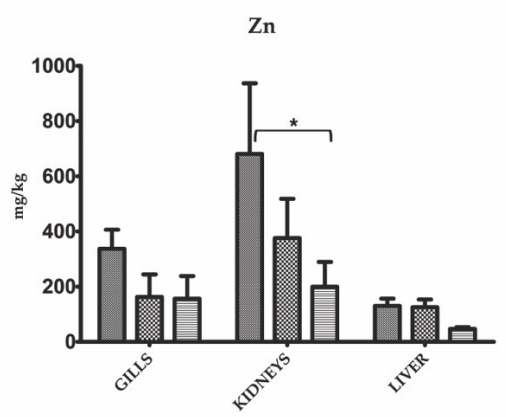

B.

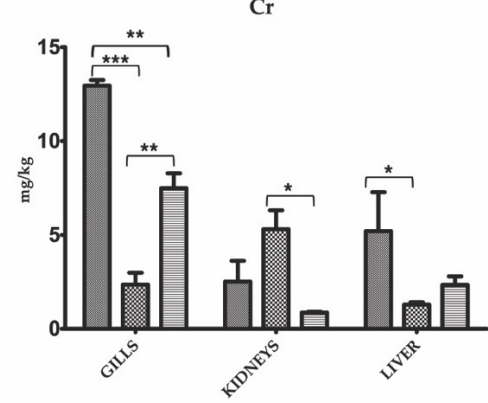

D.

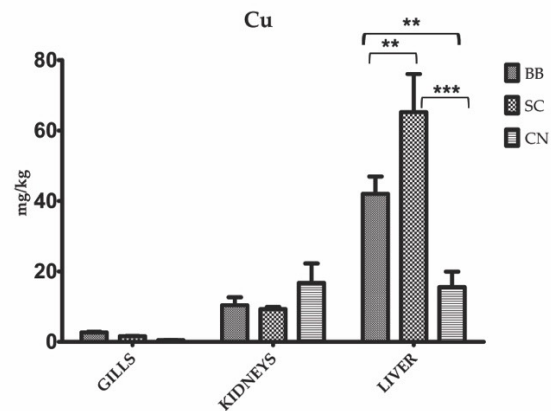

E.

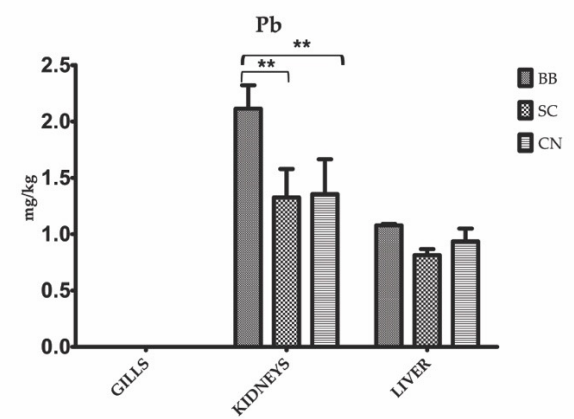

Figure 2. Heavy metal concentrations (mean \pm SEM) in the gills, kidneys, and liver of Barbus barbus (BB), Squalius cephalus (SC), and Chondrostoma nasus (CN) for cadmium (A) chromium (B), zinc (C), copper (D), lead (E) ${ }^{* * *}$ significant difference at $p<0.001 ; * *$ significant difference at $p<0.01$; * significant difference at $p<0.05$.

Renal cadmium accumulation was significantly higher in $\mathrm{BB}$ compared to $\mathrm{SC}$ and $\mathrm{CN}$, while no significant differences between species for gills and liver were noticed (Figure 2A). Similarly, $\mathrm{Pb}$ accumulated at highest level in the kidneys of carnivorous species compared to the omnivorous and herbivorous ones (Figure 2E). Zn was also bioconcentrated mainly in the kidneys, compared to the gills and livers. The carnivorous species accumulated significantly more $\mathrm{Zn}$ compared to the herbivorous fish (Figure 2C).

The gills of BB species presented the highest concentration of $\mathrm{Cr}(p<0.001$ compared to SC; $p<0.05$ compared to $\mathrm{CN}$ ). The same situation was also noticed for the liver tissue compared to the other two species (Figure 2B). By contrast, $\mathrm{Cu}$ accumulated mostly in the liver of the omnivorous species compared to the herbivorous $(p<0.01)$ and carnivorous $(p<0.005)$ ones (Figure 2D). 
Overall, $\mathrm{Cd}, \mathrm{Pb}$, and $\mathrm{Zn}$ accumulated at the highest concentrations in the kidneys, while $\mathrm{Cr}$ was recorded in the gills, and $\mathrm{Cu}$ in the liver. The BB carnivorous species was more sensitive to heavy metals and bioconcentrated the largest amount of $\mathrm{Cd}, \mathrm{Pb}, \mathrm{Zn}$, and $\mathrm{Cr}$, whereas $\mathrm{Cu}$ was accumulated at the highest level by omnivorous species. No analyzed heavy metal has accumulated mainly in the herbivorous species.

\subsection{Histopathology}

All tissues presented specific histological changes that affected the morphology of the gills, liver, and kidneys of each species (Figure 3).

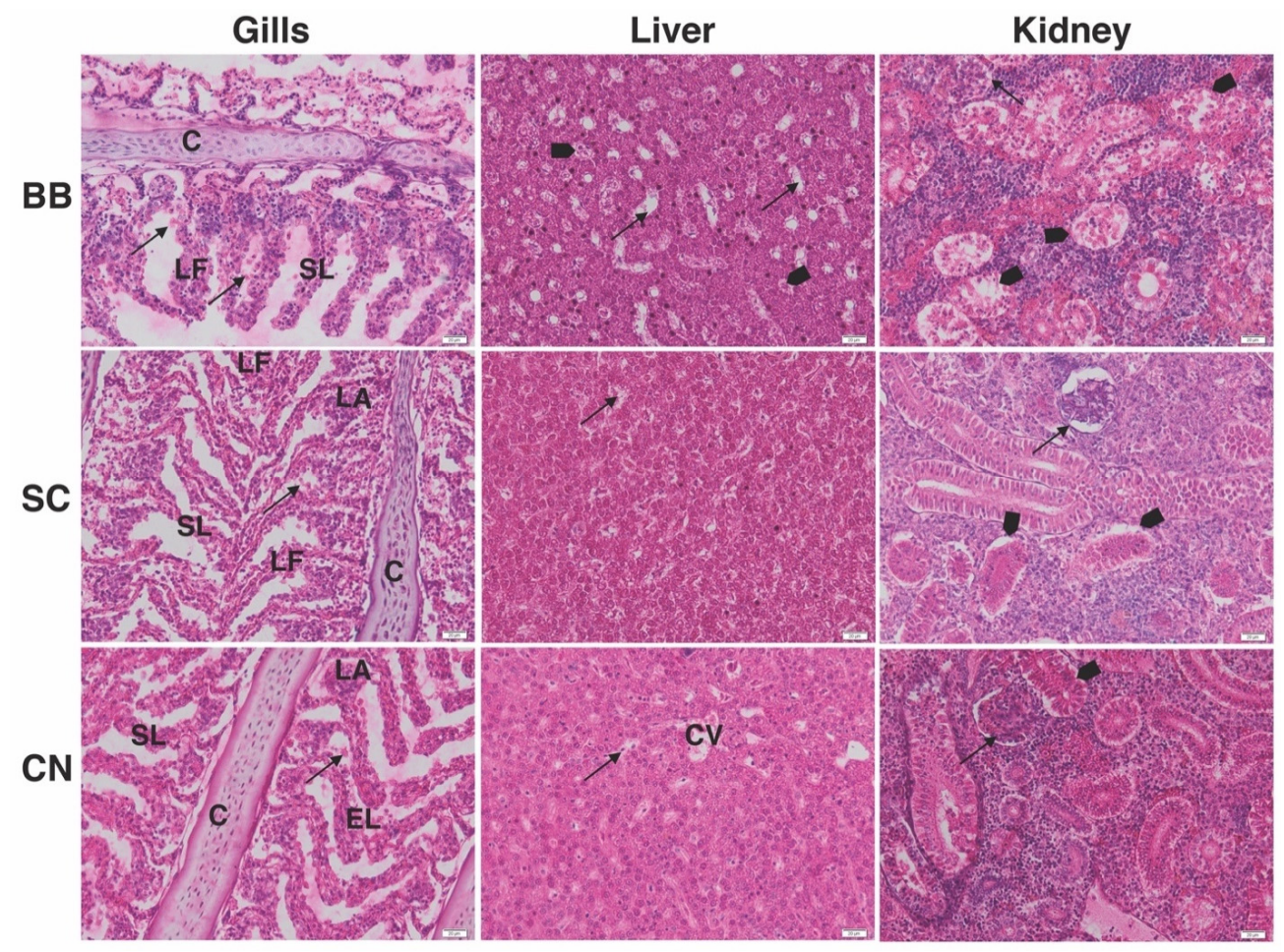

Figure 3. Microphotographs of histopathological changes observed in the captured fish: Gillscartilaginous core (C), secondary lamellae (SL), epithelial edema, epithelial necrosis and desquamation (arrow), lamellar fusion (LF), epithelial lifting (EL), lamellar aneurism (LA); Liver-centrilobular vein (CV), dilation of blood sinusoid (arrow), vacuolated hepatocytes (arrowhead); Kidneysnecrosis of renal tubules epithelium (arrowhead), shrinkage of glomerulus and increase in Bowman's space (arrow); BB-Barbus babus; CN-Chondrostoma nasus; SC—Squalius cephalus. H\&E stain. Scale bar: $20 \mu \mathrm{m}$.

The most relevant branchial changes were represented by vasodilation, epithelial necrosis, and desquamation, occasionally resulting in lamellar fusion and epithelial lifting. Many epithelial cells appeared marked by hypertrophy and hyperplasia. Contamination of the freshwater with metals caused histopathological changes in fish gills in a metal concentration and exposure time-dependent manner, mainly because these are the primary target organs of aquatic pollutants $[23,24]$. The increased bioaccumulation of $\mathrm{Cr}$ and $\mathrm{Zn}$ in the gills of all analyzed species could be correlated with the observed histopathological changes. According to Fonseca et al. [25], the impacts of metals could be of major importance and are significantly correlated with filament epithelium proliferation, lamellar fusion, and epithelial necrosis.

Hepatocyte vacuolization and sinusoid dilatation are more common than other pathological changes. Structural changes less severe than those found in the gills and kidneys suggested that the liver has a higher capacity and adaptability to counteract the metal- 
induced damage based on its stronger antioxidant system, thus preventing injuries induced by these toxins [14].

On the other hand, the kidney morphology was more affected compared to that of the gills and liver. Vacuolization of the renal epithelial cells and atrophy of the renal tubular lumens were noticed in all tested species. Glomeruli contraction and disruption of the hematopoietic tissue was also highlighted. Atrophy of renal tubules and degeneration of the Bowman's capsule were more evident for $\mathrm{CN}$.

The histopathological changes ranged between 1 and 3 for each organ and species and correlated with the specific bioaccumulation of metals into the fish tissues (Figure 4).

A.

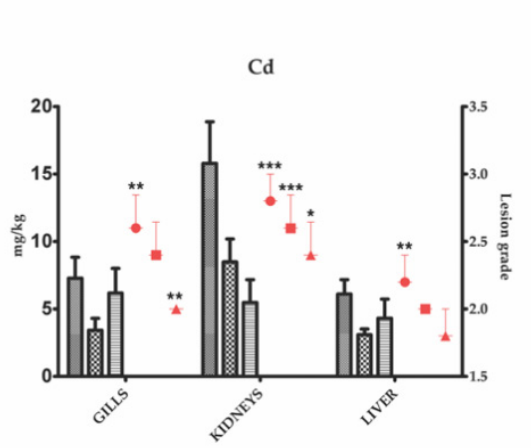

C.

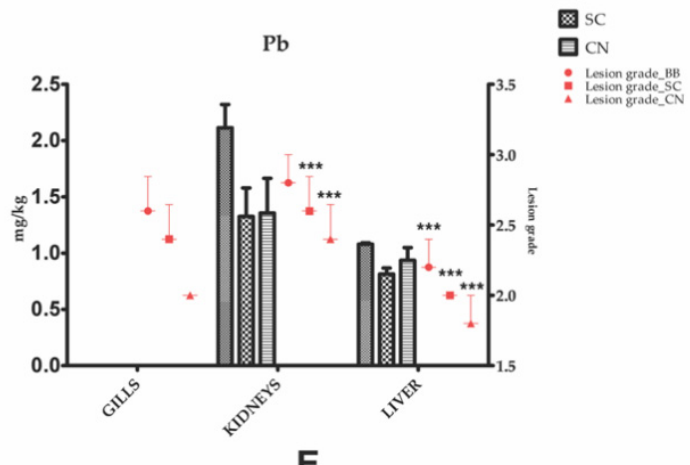

B.

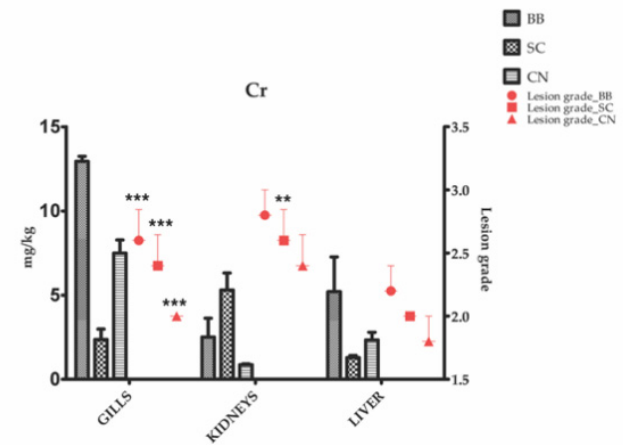

D.

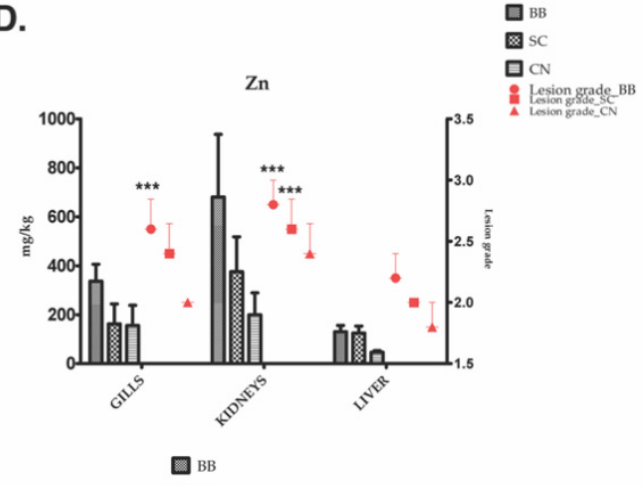

E.

Figure 4. Correlations of the histopathological lesion grade (range 1-3) in the gills, kidneys, and liver of Barbus barbus (BB), Squalius cephalus (SC), and Chondrostoma nasus (CN) with metal concentration [cadmium (A) chromium (B), zinc (C), copper (D), lead (E)] determined in the same tissues of all three analyzed species. Statistical results mark the calculated significance between the metal concentration and the lesion grade in the respective organ per each species: ${ }^{* * *}$ significant difference at $p<0.001 ;{ }^{* *}$ significant difference at $p<0.01 ;{ }^{*}$ significant difference at $p<0.05$.

The metals were simultaneously accumulated in the gills, kidneys, and liver, and this reflects their uptake by the organisms, their subsequent distribution, and significant interspecies histopathological damage differences.

The extended histopathological lesions recorded in the kidneys of the predatory fish $(2.8 \pm 0.2)$ are significantly correlated with the high concentrations of $\mathrm{Cd}, \mathrm{Pb}$, and $\mathrm{Zn}$ at the renal level $(p<0.001)$, suggesting that these metals are mainly involved in the damage 
of this tissue. A previous study noticed $\mathrm{Cd}$ and $\mathrm{Pb}$ accumulations mainly in the kidneys, while the aquatic environment and fish habitats affect the metals' bioavailability and favor its significant accumulation in predatory fish [26]. Moreover, the highest amount of renal Zn determined in our experiment confirmed Campbell's data [27], which showed that predators accumulated this heavy metal more than benthivores. This is probably due to the fact that $\mathrm{Zn}$ is accumulated mainly in sediments [28], and probably by extraction and disturbance of the redox potential of sediments and the chemical form of heavy metal, the efflux of metals from sediment to water and aquatic organism could be accelerated [29]. Furthermore, the diet of predators mainly consists of invertebrates and other benthic organisms, increasing metal accumulation in the organ and tissues of predatory fish and reflecting the pollution level of the sediment and its biota [30]. Moreover, the correlations between $\mathrm{Cd}, \mathrm{Pb}$, and $\mathrm{Zn}$ accumulation at renal level and the degree of tissue damage remain statistically significant for the omnivorous species and less significant or insignificant for the herbivorous species.

$\mathrm{Cr}$ is mainly bioaccumulated in the gills, and this observation is significantly correlated with the histopathological changes in BB $(2.6 \pm 0.24), S C(2.4 \pm 0.24)$ and CN $(2.0 \pm 0.0)$ $(p<0.001)$ because the gills are the first pathway for metals to enter into body [31,32]. Furthermore, the $\mathrm{Cr}$ concentrations in fish organs increase through biomagnification at each trophic level, taking into account that carnivorous feeders show particularly higher concentrations of this metal [33].

The liver was the target organ for $\mathrm{Cu}$ accumulations in all species and correlated significantly with the hepatic lesion grade for BB $(2.2 \pm 0.20), \mathrm{SC}(2.0 \pm 0.0)$, and CN $(1.8 \pm 0.2)(p<0.001)$. High levels of $\mathrm{Cu}$ in the hepatic tissues could be correlated with the binding proteins levels, such as metallothionein (MT) [34], which stores this essential metal to fulfill enzymatic and other metabolic demands [35]. The $\mathrm{Cu}$ bioconcentration in the hepatic tissue of SC was in agreement with other studies in which the highest concentration of it was recorded in the pelagic species (omnivorous/herbivorous) compared with the benthic (carnivorous) fish [36,37].

\subsection{Heavy Metal Bioaccumulation Activates Inflammatory Pathways in the Gills, Liver, and Kidney of BB, CN, and SC}

Recent studies have revealed that heavy metals accumulation has generated a significant increase in TNF- $\alpha$ expression in the gills, liver, and kidney of common carp [38] or in the monocytes/macrophages of Chana punctatus Bloch [39].

Figure 5 illustrates the expression of TNF- $\alpha$ in the gills, liver, and kidney of all three species exposed to metal contaminants. A large number of DAB-positive stain cells were observed in the gills, followed by the kidneys in comparison with the livers, where immunopositivity was insignificantly detected. Inflammation was especially present in the gills of the BB samples, compared to SC and CN $(p<0.001)$. The correlation between the TNF- $\alpha$ concentration in the gills and kidney of all tested species and the degree of histopathological alterations revealed a significant relationship between the two analyzed parameters, respectively: the carnivorous species with the highest expression of TNF- $\alpha$ having extended tissue damage (Figure 5C).

Our results suggested that the gills are the most sensitive organ for inflammatory processes. Taking into account the higher bioaccumulation of $\mathrm{Cd}, \mathrm{Cu}$, and $\mathrm{Zn}$, this might lead to the induction of inflammation and upregulation of pro-inflammatory TNF- $\alpha$ cytokine [40]. Western blot analysis indicated that the highest TNF- $\alpha$ level was recorded for the carnivorous species (BB), being in agreement with the histopathological damages.

\subsection{Heavy Metal Bioaccumulation Activates Reparatory Mechanisms in Gills, Liver, and Kidney of} Barbus barbus, Chondrostoma nasus, and Squalius cephalus

The structural integrity of fish's gills, kidneys, and liver also depends on cell integrity [19] and can be correlated with the expression of PCNA (proliferating cell nuclear antigen) in fish organs exposed to metal contamination [24,38], taking into account that PCNA can act as a mediator between cell cycle control and DNA repair [39]. 
A

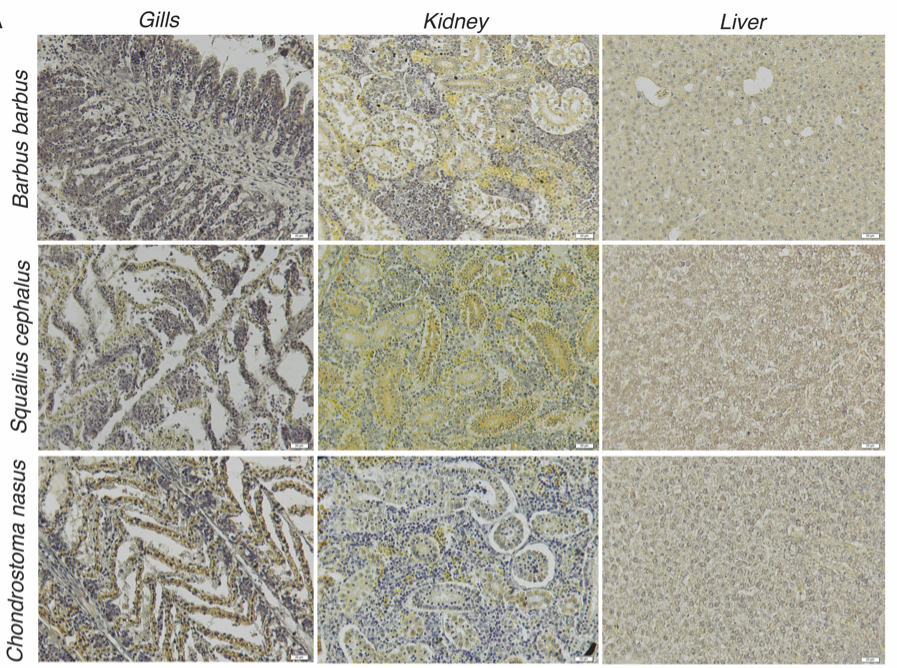

B
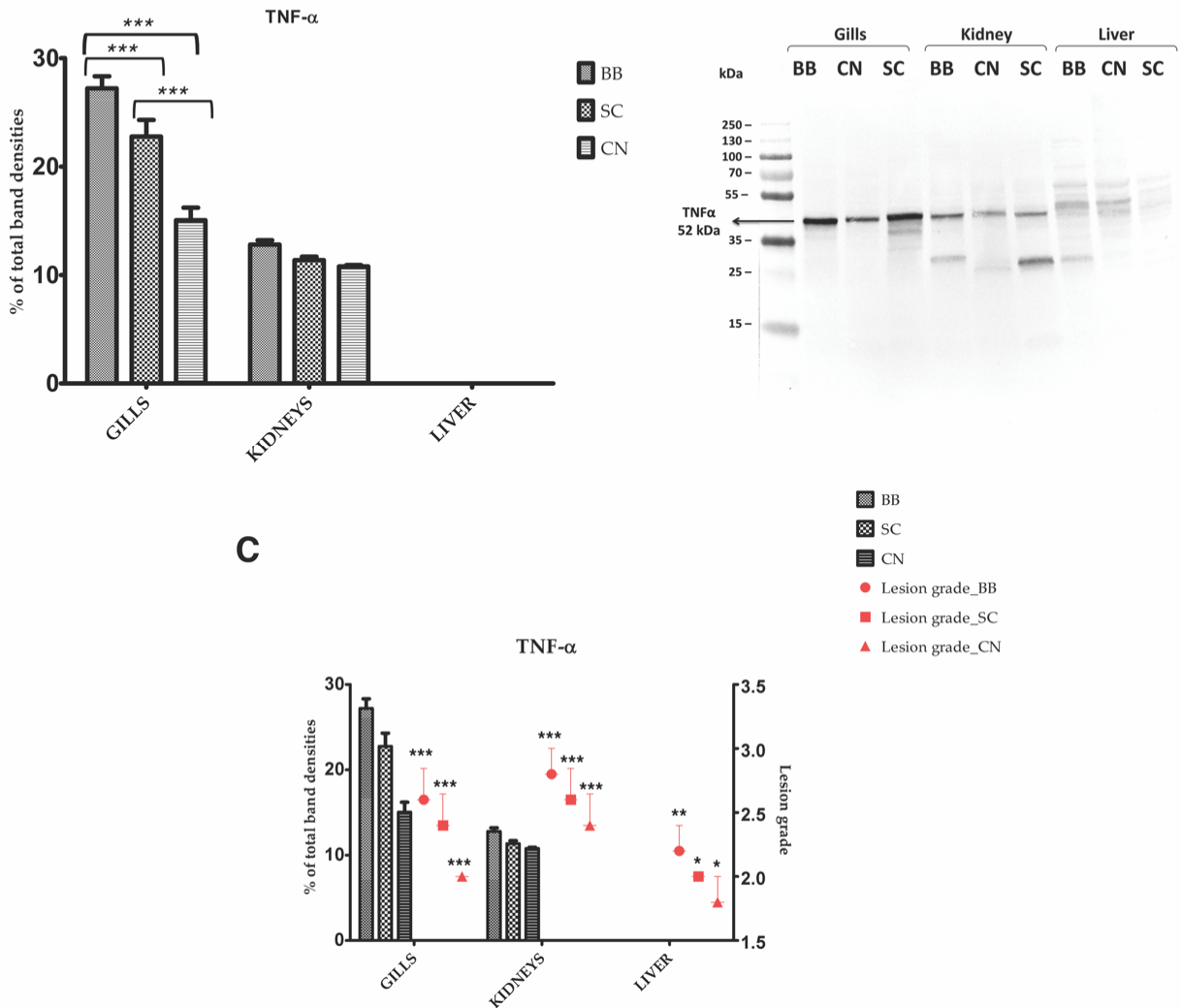

Figure 5. The effects of specific tissue heavy metal bioaccumulation on inflammatory pathway activation. (A) Immunohistochemical expression of TNF- $\alpha$ in the gills, kidney, and liver of Barbus barbus (BB), Chondrostoma nasus (CN), and Squalius cephalus (SC); (B) Western blot analysis of TNF- $\alpha$ protein levels in in the gills, kidney, and liver of Barbus barbus (BB), Chondrostoma nasus (CN), and Squalius cephalus (SC); (C) correlations of the histopathological lesion grade (ranging from 1 to 3 ) in the gills, kidneys, and liver of Barbus barbus (BB), Squalius cephalus (SC), and Chondrostoma nasus (CN) with TNF- $\alpha$ level determined in the same tissues of all three analyzed species. Statistical results mark the calculated significance between the TNF- $\alpha$ concentration and the lesion grade in the respective organ per each species: ${ }^{* * *}$ significant difference at $p<0.001$; ${ }^{* *}$ significant difference at $p<0.01$; * significant difference at $p<0.05$.

In order to assess the consequences of the toxic effects of metal-dependent organ injury and the consequent activation of a reparatory mechanism, the expression of PCNA 
was analyzed. A large number of PCNA immunopositively cells were observed in gills distributed both along the filaments and lamellae, followed by the kidney, in comparison with the liver of all three analyzed species (Figure 6A). The immunohistochemical results are consistent with the Western blot analysis outcomes (Figure 6B).

A

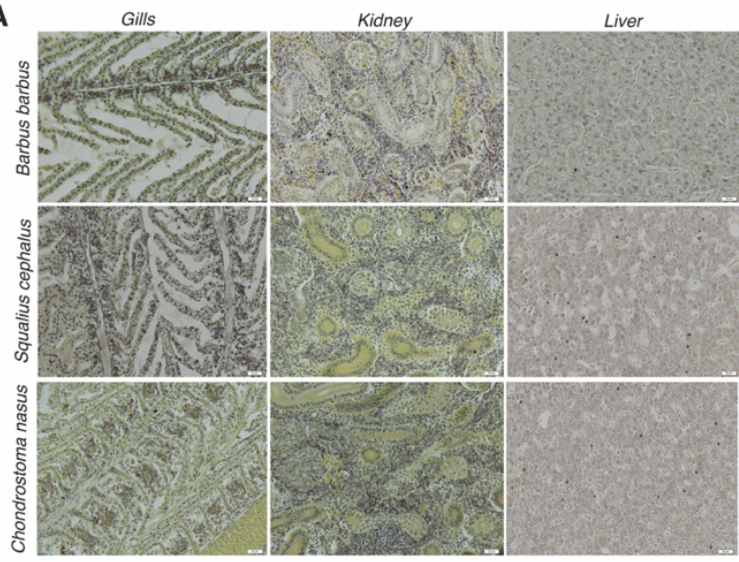

B
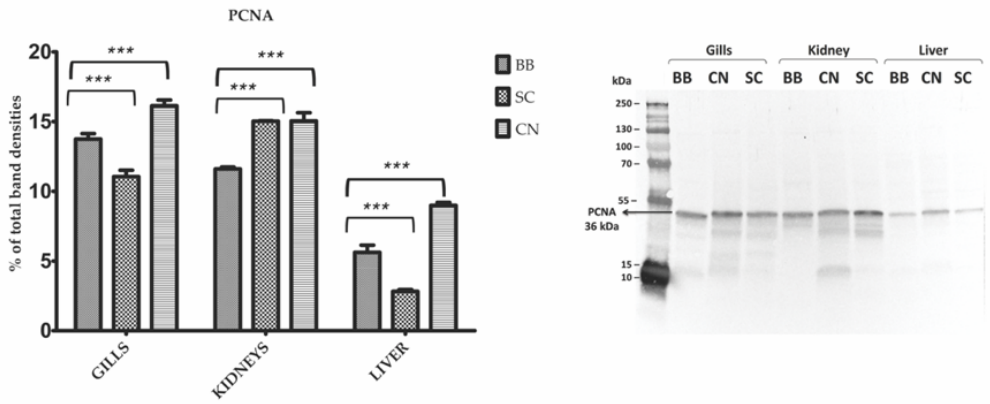

C
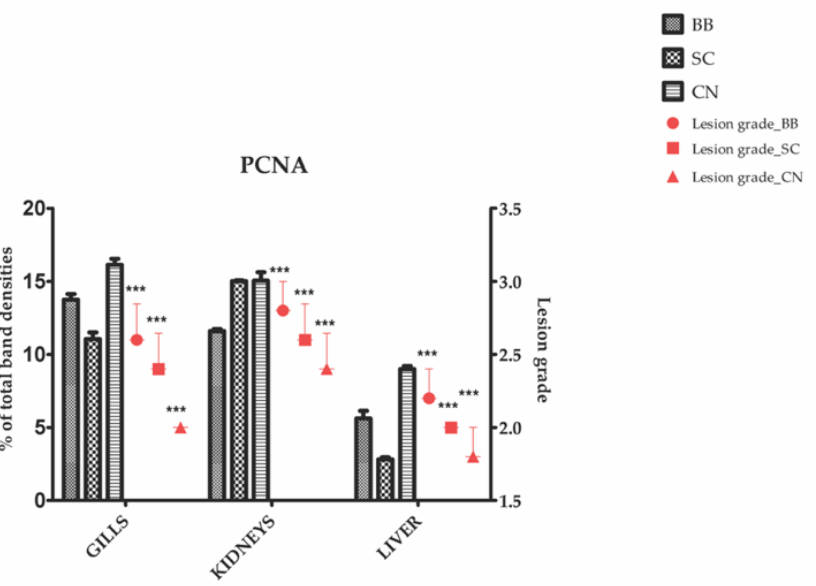

Figure 6. The effects of specific heavy metal bioaccumulation in tissues regarding the activation of repair mechanisms. (A) Immunohistochemical expression of PCNA in the gills, kidney, and liver of Barbus barbus (BB), Chondrostoma nasus (CN), and Squalius cephalus (SC); (B) Western blot analysis of PCNA protein levels in the gills, kidney, and liver of Barbus barbus (BB), Chondrostoma nasus, (CN) and Squalius cephalus (SC); ${ }^{* *} p<0.001$ in the case of gills: SC compared to BB and CN; ${ }^{* * *} p<0.001$ in the case of kidneys: BB compared to $\mathrm{CN}$ and SC; ${ }^{* * *} p<0.001$ in the case of liver: SC compared to $\mathrm{BB}$ and $\mathrm{CN}$; (C) Correlations of the histopathological lesion grade (range 1-3) in the gills, kidneys, and liver of Barbus barbus (BB), Squalius cephalus (SC), and Chondrostoma nasus (CN) with PCNA level determined in the same tissues of all three analyzed species. Statistical results mark the calculated significance between the PCNA concentration and the lesion grade in the respective organ per each species: ${ }^{* * *}$ significant difference at $p<0.001$. 
It is probably that the immunoreactivity for PCNA could be correlated with the severity of DNA injury, mainly for the gills and kidney, which might suggest that the activation of repair pathways depends on the level of alterations induced by exposure to heavy metals. Although the severity of tissue damage was recorded at the highest level for carnivorous species (BB), the repair mechanisms were unable to keep up with the damage (Figure $6 \mathrm{~B}, \mathrm{C}$ ). According to our data, the analyzed $\mathrm{CN}$ organs presented the best capacity of proliferation, meaning that PCNA expression could be correlated with liver [41], kidney [42], and gill [43] tissue regeneration. The omnivorous SC presented a similar capacity for kidney regeneration with $\mathrm{CN}$, but a lower one for the gills and liver. The correlation between PCNA expression in the three organs and food chain position of the three species revealed a significant inverse relationship, i.e., the herbivorous species likely activated the repair mechanisms at the highest level (Figure 6C). More studies are necessary to explain this observation.

\section{Conclusions}

The differentiated accumulation of heavy metals in fish species living in the same aquatic environment was attributed to the differences in the search for habitats [1], behavior, and environmental contamination [44]. It is difficult to interpret the significance of the similar concentration of heavy metals in tissues belonging to different species due to variables such as physiological tolerance or other regulatory mechanisms [45]. However, the metal concentrations in different tissues might be attributed to their specific molecular binding and metabolic characteristics [46] and could be ultimately species specific [1].

Our data suggest that there is a direct correlation between the bioconcentration level of metals in fish organs and the structural changes. The carnivorous BB species was the most affected compared to SC and $\mathrm{CN}$, and the most affected organ was the kidney. However, the restorative mechanisms expressed by PCNA synthesis could not keep up with the severity of the lesions reported. The herbivorous species presented the least extensive lesions, probably due to the higher activation of repair mechanisms and the lowest level of inflammation.

In conclusion, our data including subsequent statistical analysis suggest that feeding behavior could be correlated with the heavy metals-induced histopathological alterations in the gills, kidney, and liver, and histological analyses could be used for a deeper evaluation of aquatic environment safety and analysis of aquatic ecosystems.

Author Contributions: Conceptualization, A.H.; methodology B.O.; A.H.; A.D.; formal analysis, B.O.; P.A.; H.H.; C.B.; V.L.; A.F.; E.B.; S.H.; S.K.; L.N.; T.N.; V.J.; D.G.; K.G.; M.S.; investigation, B.O.; P.A.; H.H.; C.B.; V.L.; A.F.; E.B.; S.H.; S.K.; L.N.; T.N.; V.J; D.G.; K.G.; M.S.; resources, A.D.; writing—original draft preparation, B.O.; P.A.; writing—review and editing; visualization, A.H.; A.D.; supervision, A.H.; A.D.; project administration, A.H.; funding acquisition, A.D. All authors have read and agreed to the published version of the manuscript.

Funding: This research was funded by the Executive Agency for Higher Education, Research, Development and Innovation Funding (UEFISCDI) within the Project no. 10PCCF/-PN-III-P4-IDPCCF2016-0114-RADAR.

Institutional Review Board Statement: The study was conducted according to the guidelines of the Declaration of Helsinki and approved by the Ethics Committee of the Vasile Goldis Western University of Arad (18/4 April 2015).

Data Availability Statement: The data are available upon request from corresponding author.

Conflicts of Interest: The authors declare no conflict of interest. The funders had no role in the design of the study; in the collection, analyses, or interpretation of data; in the writing of the manuscript, or in the decision to publish the results. 


\section{References}

1. Sánchez-Bayo, F. Sources and Toxicity of Pollutants. In Ecological Impacts of Toxic Chemicals; Sánchez-Bayo, F., van den Blink, P., Mann, R.M., Eds.; Bentham Science Publisher Ltd.: Potomac, MD, USA, 2011; pp. 3-12.

2. Nriagu, J.O. A global assessment of natural sources of atmospheric trace metals. Nature 1989, 338, 47-49. [CrossRef]

3. Briffa, J.; Sinagra, E.; Blundell, R. Heavy metal pollution in the environment and their toxicological effects on humans. Helyon 2020, 6, e04691. [CrossRef] [PubMed]

4. Schäfer, S.; Buchmeier, G.; Claus, E.; Duester, L.; Heininger, P.; Körner, A.; Mayer, P.; Paschke, A.; Rauert, C.; Reifferscheid, G.; et al. Bioaccumulation in aquatic systems: Methodological approaches, monitoring and assessment. Environ. Sci. Eur. 2015, 27, 5. [CrossRef] [PubMed]

5. Jezieerska, B.; Witeska, M. Uptake and accumulation in fish living in polluted waters. In Soil and Water Pollution Monitoring, Protection and Remediation; Twardowska, I., Allen, H.E., Häggblon, M.M., Eds.; NATO Science Series IV Earth and Environmental Sciences; Springer: Berlin/Heidelberg, Germany, 2006; Volume 69, pp. 107-114.

6. Novikova, L.V.; Gaisin, A.R.; Stepanova, N.Y. The Content of Metals in Tissues and Organs of Fish of Different Trophic Levels in the Estuary of the Kama River. In IOP Conference Series: Earth and Environmental Science; IOP Publishing: Bristol, UK, 2019; Volume 272, p. 022211.

7. Weber, P.; Behr, E.R.; Knorr, C.D.L.; Vendruscolo, D.S.; Flores, E.M.M.; Dressler, V.L.; Baldisserotto, B. Metals in the water, sediment and tissues of two fish species from different trophic levels in a subtropical Brazilian river. Microchem. J. 2013, 106, 61-66. [CrossRef]

8. Shinn, C.A.; Dauba, F.; Grenouillet, G.; Guenard, G.; Lek, S. Temporal variation of heavy metal contamination in fish of the river lot in southern France. Ecotoxicol. Environ. Saf. 2009, 72, 1957-1965. [CrossRef] [PubMed]

9. Prashanth, L.; Kattapagari, K.K.; Chitturi, R.T.; Baddam, V.R.; Prasad, L.K. A review on role of essential trace elements in health and disease. JNTR Univ. Health Sci. 2015, 4, 75-85.

10. Mieiro, C.L.; Duarde, A.C.; Pereira, M.E.; Pacheco, M. Mercury accumulation patterns and biomedical endpoints in wild fish (Liza aurata): A multiorgan approach. Ecotox. Environ. Safety 2011, 74, 2225-2232. [CrossRef] [PubMed]

11. Mahboob, S.; Kausar, S.; Jabeen, F.; Sultana, S.; Sultana, T.; Al-Ghanim, K.A.; Hussain, B.; Al-Misned, F.; Ahmed, Z. Effect of heavy metals in liver, kidney, gills and muscles of Cyprinus carpio and Wallago attu inhabited in the Indus. Braz. Arch. Biol. Technol. 2016, 59, 1-10. [CrossRef]

12. Lushchak, V.I. Contaminant induced oxidative stress in fish: A mechanistic approach. Fish Physiol. Biochem. 2016, 42, 711-747. [CrossRef] [PubMed]

13. Sabullah, M.K.; Ahmad, S.; Shukor, M.Y.; Gansau, A.J.; Syed, M.A.; Sulaiman, M.R.; Shamaan, N.A. Heavy metal biomarkers: Fish behavior, cellular alteration, enzymatic reaction and proteonic approaches. Int. Food Res. J. 2015, 22, 435-454.

14. Hermenean, A.; Damache, G.; Albu, P.; Ardelean, A.; Ardelean, G.; Ardelean, D.P.; Horge, M.; Nagy, T.; Braun, M.; Zsuga, M.; et al. Histopathological alterations and oxidative stress in liver and kidney of Leuciscus cephalus following exposure to heavy metals in the Tur River, North Western Romania. Ecotoxicol Environ. Saf. 2015, 119, 198-205. [CrossRef] [PubMed]

15. Li, S.; Tan, H.-Y.; Wang, N.; Feng, Y. Insights into the role and interpendence of oxidtive and inflammation in liver diseaes. Oxid. Med. Cell Longev. 2016, 2016. [CrossRef] [PubMed]

16. Sun, Y.; Li, Y.; An, J.; Liu, Z.; Chen, Q. Antioxidative and inflammatory responses in spleen and head kidney of Yellow Catfish (Pelteobagrus fulvidraco) induced by waterborne cadmium exposure. Turk. J. Fish. Aquat. Sci. 2019, 20, 8796.

17. Petrovici, M.; Paciogl, O. Heavy metal concentrations in two species of fish from the Crișul Negru River, Romania. AACL Bioflux. 2010, 3, 51-60.

18. Banarescu, P.; Murgoci, A. Pisces-Osteichthyes: (Peşti Ganoizi şi Osoşi); Editura Academiei Romane: Bucureti, Romania, 1964.

19. Gergely, I.; Oprea, J.E.; Sion, L.; Călin, P.G. The influence of structural changes and ichtyofauna abundance on the ecological state of the Crisuri hydrographic area. AACL Bioflux 2011, 4, 170-179.

20. Abdel-Moneim, M.; Al-Kahtani, M.A.; Elmenshawy, O.M. Histopathological biomarkers in gills and liver of Oreochromis niloticus from polluted wetland environments, Saudi Arabia. Chemosphere 2012, 88, 1028-1035. [CrossRef]

21. Triebskorn, R.; Telcean, I.; Casper, H.; Farkas, A.; Sandu, C.; Stan, G.; Colarescu, O.; Dori, T.; Kohler, H.R. Monitoring pollution in River Mures, Romania, part II: Metal accumulation and histopathology in fish. Environ. Monit. Assess. 2008, 4, 177-188. [CrossRef]

22. Mishra, A.K.; Mohanty, B. Acute toxicity impacts of hexavalent chromium on behavior and histopathology of gill, kidney and liver of the freshwater fish, Channa punctatus (Bloch). Environ. Toxicol. Pharmacol. 2008, 26, 136-141. [CrossRef]

23. Tchounwou, P.B.; Yedjou, C.G.; Patlolla, A.K.; Sutton, D.J. Heavy Metal Toxicity and the Environment. Exp. Suppl. 2012, 101, 133-164. [PubMed]

24. Hermenean, A.; Gheorghiu, G.; Stan, M.S.; Herman, H.; Onita, B.; Ardelean, D.; Ardelean, A.; Braun, M.; Zsuga, M.; Keki, S.; et al. Biochemical, Histopathological and molecular responses in gills of Leuciscus cephalus exposed to metals. Arch. Environ. Contam. Toxicol. 2017, 73, 607-618. [CrossRef]

25. Fonseca, A.R.; Sanches Fernandes, L.F.; Fontainhas-Fernandes, A.; Monteiro, S.M.; Pacheco, F.A.L. The impact of freshwater metal concentrations on the severity of histopathological changes in fish gills: A statistical perspective. Sci. Total Environ. 2017, 599-600, 217-226. [CrossRef] [PubMed]

26. Moiseenko, T.I.; Gashkina, N.A. Distribution and bioaccumulation of heavy metals $(\mathrm{Hg}, \mathrm{Cd}$ and $\mathrm{Pb})$ in fish: Influence of the aquatic environment and climate. Environ. Res. Lett. 2020, 15, 115013. [CrossRef] 
27. Campbell, K.R. Concentrations of heavy metals associated with urban runoff in fish living in storm water treatment ponds. Arch Environ. Contam. Toxicol. 1994, 27, 352-356. [CrossRef]

28. Bochenek, I.; Protasowicki, M.; Brucka-Jastrzebska, E. Concentrations of $\mathrm{Cd}, \mathrm{Pb}, \mathrm{Zn}$, and $\mathrm{Cu}$ in roach Rutilus rutilus (L.) from the lower reaches of the Oder River, and their correlation with concentrations of heavy metals in bottom sediments collected in the same area. Arch. Pol. Fish. 2008, 16, 21-36. [CrossRef]

29. Fan, W.H.; Wang, W.X.; Chen, J.S. Geochemistry of Cd, Cr, and Zn in highly contaminated sediments and its influences on assimilation by marine bivalves. Environ. Sci. Technol. 2002, 36, 5164-5171. [CrossRef]

30. Rajkowska, M.; Protasowicki, M. Distribution of metals (Fe, Mn, $\mathrm{Zn}, \mathrm{Cu}$ ) in fish tissues in two lakes of different trophy in Northwestern Poland. Environ Monit Assess. 2013, 185, 3493-3502. [CrossRef]

31. Velma, V.; Tchounwou, P.B. Hexavalent chromium-induced multiple biomarker responses in liver and kidney of Gold fish, Carassius auratus. Environ. Toxicol. 2009, 26, 649-656. [CrossRef]

32. Bakshia, A.; Panigrahib, A.K. A comprehensive review on chromium induced alterations in fresh water fishes. Toxicol. Rep. 2018, 5, 440-447. [CrossRef] [PubMed]

33. Obasohan, E.E. Heavy metals concentrations in the offal, gill, muscle and liver of a freshwater mudfish (Parachanna obscura) from Ogba River, Benin city. Nigeria. Afr. J. Biotechnol. 2007, 6, 2620-2627. [CrossRef]

34. Gorur, F.K.; Keser, R.; Akcay, N.; Dizman, S. Radioactivity and heavy metal concentrations of some commercial fish species consumed in the Black Sea Region of Turkey. Chemosphere 2012, 87, 356-361. [CrossRef] [PubMed]

35. Roesijadi, G. Metallothionein and its role in toxic metal regulation. Comp. Biochem. Physiol. 1996, 113, 117-123. [CrossRef]

36. Abdallah, M.A. Trace element levels in some commercially valuable fish species from coastal waters of Mediterranean Sea, Egypt. J. Mar. Syst. 2008, 73, 114-122. [CrossRef]

37. Bawuro, A.A.; Voegborlo, R.B.; Adimado, A.A. Bioaccumulation of Heavy Metals in Some Tissues of Fish in Lake Geriyo, Adamawa State, Nigeria. J. Environ. Public Health 2018, 2018. [CrossRef] [PubMed]

38. Rajeshkumar, S.; Liu, Y.; Ma, J.; Duan, H.Y.; Li, X. Effects of exposure to multiple heavy metals on biochemical and histopathological alterations in common carp Cyprinus carpio L. Fish Shellfish Immunol. 2017, 70, 461-472. [CrossRef]

39. Choundhury, C.; Mazumder, R.; Biswas, R.; Sengupta, M. Cadmium exposure induces inflammation through the canonical NF-kB pathway in monocytes/macrophages of Chana punctatus Bloch. Fish Shellfish Immunol. 2021, 110, 116-126. [CrossRef]

40. Wang, Z.J.; Liu, Z.H.; Jin, L.; Pu, D.Y.; Huang, J.; Zhang, Y.G. Transcriptome profiling analysis of rare minnow (Gobiocypris rarus) gills after waterborne cadmium exposure. Comp. Biochem. Physiol. Part D 2016, 19, 120-128. [CrossRef]

41. Assy, N.; Gong, Y.; Zhang, M.; Pettigrew, N.M.; Pashniak, D.; Minuk, G.Y. Use of proliferating cell nuclear antigen as a marker of liver regeneration after partial hepatectomy in rats. J. Lab. Clin. Med. 1998, 131, 251-256. [CrossRef]

42. Adrianova, N.V.; Buyan, M.I.; Zorova, L.D.; Pevzner, I.B.; Popkov, V.A.; Babenko, V.A.; Silachev, D.N.; Plotnikov, E.Y.; Zorov, D.B. Kidney cells regeneration: Dediferentiation of tubular epithelium, resident stem cells and possible niches for renal progenitors. Int. J. Mol. Sci. 2019, 20, 6326. [CrossRef]

43. Mierzwa, A.; Nguyen, F.; Xue, M.; Jonz, M.G. Regeneration of gills fillaments and replacement of serotonergic neuroepithelial cells in adult Zebrafish (Danio rerio). Respir. Physiol. Neurobiol. 2020, 274, 103366. [CrossRef]

44. Mwashote, B.M. Levels of cadmium and lead in water, sediments and selected fish species in Mombasa, Kenya. West. Indian Ocean J. Mar. Sci. 2003, 2, 25-34. [CrossRef]

45. Mokhtar, M.B.; Aris, A.Z.; Munusamv, V.; Praveena, S.M. Assessment level of heavy metals in Penaeus monodon and Oreochrimis spp in selected aquaculture ponds of high densities developement area. Eur. J. Sci. Res. 2009, 30, 348-360.

46. El-Sadaawy, M.M.; El-Said, G.F.; Sallam, N.A. Bioavailability of heavy metals in fresh water Tilapia nilotica (Oreachromis niloticus Linnaeus, 1758): Potential risk to fishermen and consumers. J. Environ. Sci. Health B 2013, 48, 402-409. [CrossRef] [PubMed] 